(3)

Volume 14, 2017

\title{
THE ELEMENTS WAY: \\ EMPOWERING PARENTS, EdUCATORS, AND MENTORS IN THE AGE OF NEW MEDIA
}

\author{
Dr. Gila Cohen Zilka \\ Bar-Ilan University, Achva Academic gila.zilka@gmail.com \\ College, Israel
}

\begin{abstract}
Aim/Purpose

This study was designed to examine the effectiveness of mentor's work with immigrant children and adolescents at risk, using the Elements Way.

Background

The New Media offers our "screen kids" a lot of information, many behavioral models, and a new type of social communication. The Elements Way is an educational method designed to enhance openness, development, breakthroughs, goal achievement, and transformation in the age of media and social networks.

Methodology The Elements Way was developed following research on communication in the diversified media, especially new media such as Facebook, WhatsApp, and television reality shows, and the study is an examination of the effectiveness of mentors' work with immigrant children and adolescents at risk, using the Elements Way. All mentors had been trained in the Elements Way. The study population included 640 mentors working with immigrants' children in Israel. The work was conducted in 2010-2013. The mixed-methods approach was selected to validate findings.

Contribution Empowering children and enhancing their ability to cope; Creating openness and sharing, making children more attentive to the significant adults in their lives; Supporting children who face the complex reality that characterizes our age.

Findings Significant differences were found in the mentors' conduct with the children. Work programs were designed and implemented with care and consistency, and mentors succeeded in generating change within the children and achieving desired goals. Of the 640 participating mentors, 62 were not able to promote the child, and interviews with them revealed that their work with the children was not consistent with the Elements Way and began from a different vantage point.
\end{abstract}

Recommendations Success factors: Self-awareness and awareness of one's surroundings. Empathy. for Practitioners Willingness to engage in significant interactions. Self-cleansing and self-

Accepting Editor: Eli Cohen | Received: November 29, 2016 | Revised: February 27, 2017 | Accepted: March 17, 2017.

Cite as: Zilka, G. C. (2017). The elements way: Empowering parents, educators, and mentors in the age of new media. Issues in Informing Science and Information Technology Education, 14, 101-119. Retrieved from http://www.informingscience.org/Publications/3702

(CC BY-NC 4.0) This article is licensed to you under a Creative Commons Attribution-NonCommercial 4.0 International License. When you copy and redistribute this paper in full or in part, you need to provide proper attribution to it to ensure that others can later locate this work (and to ensure that others do not accuse you of plagiarism). You may (and we encourage you to) adapt, remix, transform, and build upon the material for any non-commercial purposes. This license does not permit you to use this material for commercial purposes. 
reflection. Ability to engage in a personal and interpersonal dialogue. Ability to accept and contain the child. Cooperation with the child in creating a work program and assisting the child to achieve the goals that were set in the program.

Recommendation Future studies should focus on analyzing the discussions of children and adofor Researchers lescents, to add depth to our insights regarding children and adolescents' perception of the mentors' work from their perspective.

Impact on Society Finding the "keys" to openness, development, goal achievement, and transformation in our work with "screen kids."

Future Research Studies that are designed to examine the effectiveness of mentor's work with immigrant children and adolescents at risk, using the Elements Way.

Keywords screen kids, empowering, new media, immigrant children, children at risk, mentors, the Elements Way

\section{INTRODUCTION}

Children nowadays are exposed to a wide variety of information sources and channels, and this exposure makes them scatter-brained and generates great confusion, focus and concentration difficulties, attention and adjustment problems, and a blurring of boundaries and values. The abundance of information sources and channels forces us, more than ever, to be attentive to children, help them, and support them. What are the "keys" to openness, development, goal achievement, and transformation in our work with these "screen kids"? How can we empower them and their coping abilities? How can we create openness and cooperation that will make them listen to us? How can we support them to cope with the complex reality that characterizes our age? How can we use our knowledge and authority so that they do not weaken our children and, instead, empower and strengthen them?

The Elements Way, an innovative method for working with children in our age, will help us help children, teach them to deal successfully with the new reality, and empower them and empower ourselves as meaningful parents, educators, and adults. Positive communication, acceptance, and connecting to one's powers and free will are the tools we possess for educating our children. When we say "educate a child" we really mean "mentor the child," help children develop their own powers and face difficulties, while relating to their free will and finding the balance that is appropriate for them. The main goal is to empower parents, educators, and mentor, thus empowering their encounter with the children, so that they can support the children, and be there for them whatever they face.

\section{Children aNd New Media}

Studies of children and media - children and television, children and social networks, etc., - have revealed that, on the one hand, children feel that media - of all varieties - is an additional compensating sphere where their needs are met. On the other hand, they are exposed to greater complexities with which they have to deal, and these complexities are greater than ever before. They are exposed to the blurring of boundaries between private and public, intimacy and sharing, and between adjustment to environmental norms and autonomous choice. Children watch television because they find that the programs provided an additional - at times alternative - source for understanding the society in which they live and the process of socialization they are supposed to experience. Television is the arena on which there are many permanent and transient characters with whom the child creates parasocial interactions; these "like social" interactions provide children with an opportunity to examine "how to behave" in various situations. For children, television programs provide essential social learning and present models for each and every social role, without exposing children to criticism or feedback that could make them feel attacked or exposed. Television broadens children's horizons, and they feel that the media open new horizons for their development (Bickham \& Rich, 2006; Leung, 2013; McQuail, 2010; Rideout, Foehr \& Roberts, 2010; Vandewater, Bickham \& Lee, 2006; West \& 
Turner, 2007; Zilka, 2014, 2016a). Children feel that social networks expand their ability to form communication with others and empower a sense of social connection. The networks provide a feeling of belonging, the experience of close friendships, and of being socially accepted, as opposed to feelings of loneliness and alienation. For children, such interactions create a sense of self-worth and being needed and of being a major contributor to their environment. They also provide them with an opportunity to express their skills and receive feedback and appreciation from their surroundings. Children feel that social networks expand their adjustment skills and help them develop skill that are appropriate to the new surroundings and the society in which they live (Duerager \& Livingstone, 2012; Livingstone, 2015; Livingstone, Marsh, Plowman, Ottovordemgentschenfelde, \& FletcherWatson, 2015; Ofcom, 2006, 2007; Zilka, 2014, 2016b).

However, children are exposed to many sources of information and to more complex situations than ever before. They operate in an environment that gives them a feeling of a vast space, a space without boundaries that offers infinite possibilities. It is easier to hurt people online than it is to do so face to face. Being invisible - "I'm online but no one can see me" - could lead users into risk situations. Users who were not previously defined as being at risk could reach - given frequent use many hours a day, and without clear boundaries or supervision - severe situations of risk and hurting others (Atwal, Millwood Hargrave, Sancho, Agyeman, \& Karet, 2003; Comstock \& Scharrer, 2007; Gatfield \& Millwood Hargrave, 2003; Holbert \& Stephenson, 2003; Livingstone, 2007, 2008; Millwood Hargrave, 2007; Millwood Hargrave \& Livingstone, 2009). Information on social networks is open for all to see, and therefore the impact and scope of injury are severe, especially when they involve children. Children have a low ability to contain broad and frequent injuries. Studies I have conducted have shown that children feel that their immediate surroundings do not manage to provide them with enough information on how to manage in today's world, and these feelings are enhanced through using media and viewing their content. Children feel that the interactions they experience in the media are significant, but such interactions do not provide children with the feedback that is so essential to their development - the feedback received from significant people who care about these children and their emotional wellbeing. More than ever, communication media and social networks exposed children to various models of parenting, human behavior, and children's and adolescents' behavior, and these models affect the shaping of children's personality. More than ever, the role of the significant adult is more complex and less clear cut.

As adults who are significant to the children, the change in children's environment makes us take a path that would empower us and our children and fulfill our role as significant educators who shape the next generation: We will use The Elements Way so that children will want us to reach them, will want to reach us, and will want us to help them grow and develop. Positive communication, acceptance, and connecting to strengths and to free will are the tools we have when we want to educate our children. When we speak about "educating a child" we actually mean "mentoring a child" - helping children develop their strengths and deal with difficulties, while connecting to their free will and finding their equilibrium.

Which "keys" will lead to openness, development, goal achievement, and transformation in our work with the "screen kids"? How can we empower them and enhance their coping abilities? Can we create the kind of openness and cooperation that would make them listen to us? How can we support them to cope with the complex reality that characterizes our age? How can we use our knowledge and authority so that they do not weaken our children, and instead empower and strengthen them? The Elements Way, an innovative method for working with children in our age is our tool for helping children, empowering them while empowering ourselves as parents, educators, and significant adults, and helping them deal with the new reality. The main goal is to empower parents, educators, and mentors, thus empowering their encounter with the children, so that these significant adults can support children and be there for them whenever and wherever needed. 


\section{THE ELEMENTS WAY}

The Elements Way is an educational method designed to enhance openness, development, breakthroughs, goal achievement, and transformation. The main aim of the Elements Way is to empower the mentors working with the children. Such empowerment should better their encounter with the children and strengthen them and their role as significant adults in the life of the children. Through their work, the mentors strive to enable the children to cultivate the most significant components in child development, namely fostering the child's strengths and uniqueness, building social skills for becoming involved and integrated with the child's host society, culture, and environment. The method's three central elements are positive communication - speaking the language of love, acceptance, and connecting to one's strength and free will (Daloz, 1987; Hamre \& Pianta, 2001, 2005; Hamre, Pianta, Downer, \& Mashburn, 2008; Howes \& Ritchie, 2002; Myers \& Pianta, 2008; Pianta, Belsky, Vandergrift, Houts, \& Morrison, 2008; Pianta, Hamre, \& Stuhlman, 2002; RimmKaufman, La Paro, Downer, \& Pianta, 2005; Seligman, Steen, Park, \& Peterson, 2005; Zilka, 2014, 2015, 2016b.)

\section{POSITIVE COMMUNICATION - SPEAKING THE LANGUAGE OF LOVE}

The primary meaning of positive communication is holding a meaningful dialogue with the child. Children must feel that we are here for them and with them. A dialogue with children must be an existential one, a dialogue that clarifies to children that we treat their problems with utter seriousness, view these problems as existential problems, and want to help the child open up and develop, as opposed to attempts at persuasion, arguments, etc. Discussing problems is not enough; we must regard children and their difficulties as essential problems, which we should actively help them solve. We will emphasize the way things are said, the choice of words, and a heart-to-heart discourse.

\section{ACCEPTANCE}

Acceptance means accepting ourselves and others as we are and using this as a starting point that will lead to openness, development, and change. When individuals accept themselves, they perceive themselves as they are, with their strengths, weakness, and difficulties, and thus is created a channel of inner and outer communication which can lead to self-love, openness, and development. When people accept the other, they accept them as they are, and this opens up a channel of communication between them which could lead to love of the other, to openness, and development. Accepting children as they are does not mean they do not have to change. On the contrary, it means we accept our innate qualities as a foundation for growth and expansion. Nothing has to be shed, but things must undergo a process of openness and development to channel children's strengths in positive directions.

\section{CONNECTING TO STRENGTHS}

We each have our inborn strengths. There are those of us who, for a variety of reasons, lose their awareness of these strengths. They are unaware of them, not connected to their free will, and do not feel at liberty to exercise free choice. Therefore, they are not able to realize and fulfill themselves. We must be on the alert to locate our child's strengths in various realms, and having located them, create opportunities to foster and encourage them.

One of the main tools of The Elements Way is cleansing of self-monitoring. Using the language of love, we learn not to repress and, certainly, not to let out our anger our on the child or on anyone else, but rather, to be aware of things: to observe, cleanse, and take care of them. Our cleansed position will allow us to reconnect to our strengths so that we may create, do, and act in a way that will lead to our self-realization and to our children's self-realization. We transform aggression, doubt, condemnation, insecurity, lack of esteem, feelings of guilt, grudges, hate, and emptiness into opposite feelings, which emanate from love, not fear, and from self-acceptance, acceptance of the other, help, and empathy. 
Here is a way that could help the process of observing our voices of thoughts and feelings. When something happens, we should ask ourselves at each stage of the event what path we are on and what are the sensations that accompany us.

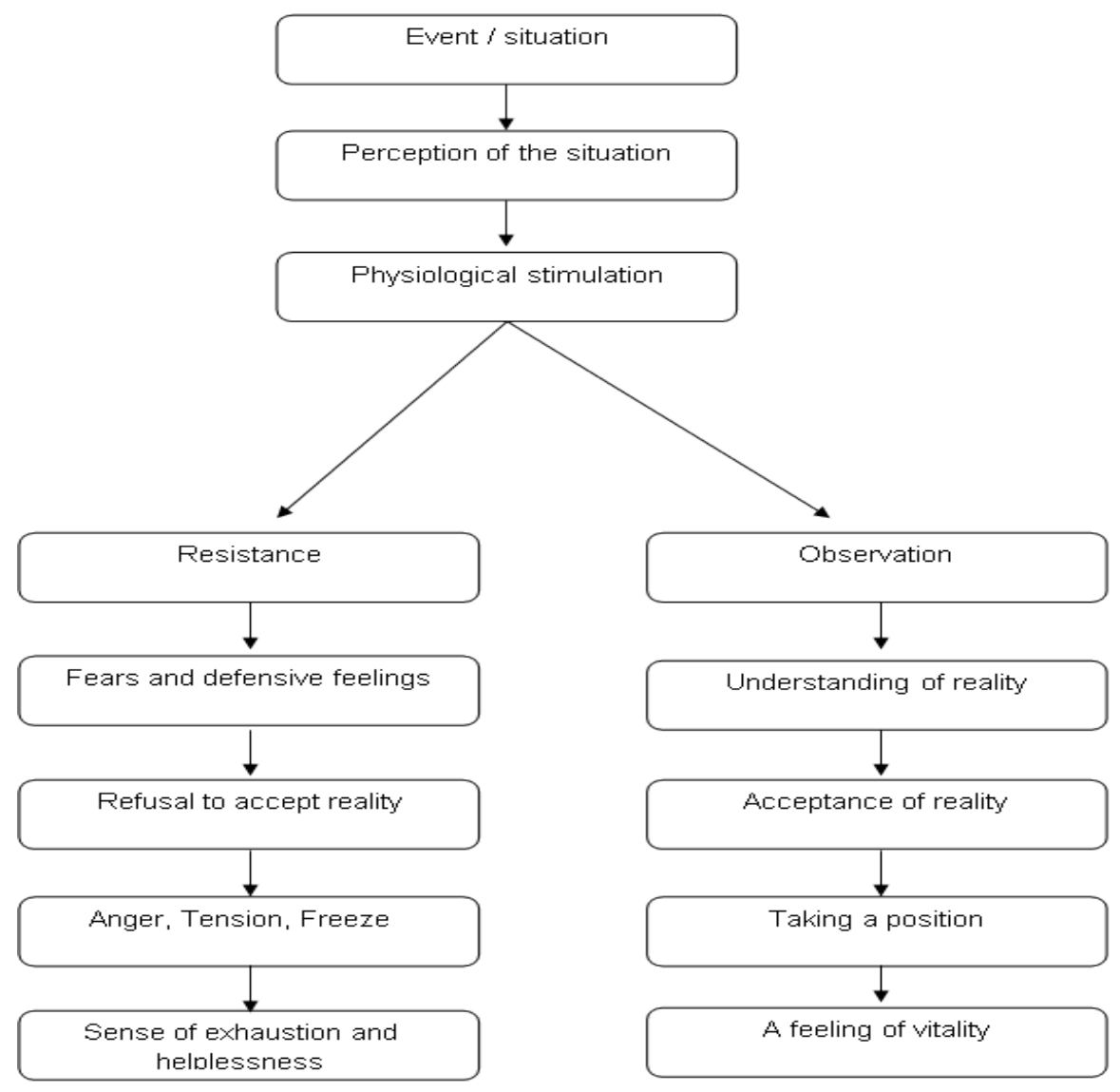

Figure 1: The Thought-Sensation-Feeling-Action Model (Zilka 2014, p. 96)

Using Figure 1 for guidance, we will look at the course of action we have chosen. Did we go along the path of observing the event, accepting reality, and acting in a way that gave us a sense of vitality? Or did we choose a path of resisting reality, giving rise to anger and fear, a feeling of being assaulted and therefore a need to defend ourselves and attack?

According to the Elements Way, the basic guiding principle for constructing a plan of action is the "child's best interest." We do not deal with one problem or another, rather, we want to help the child. The key to success is finding balance. We will help the child find the point of equilibrium, because whatever the child has - any characteristic and attribute - is most likely something that child needs, but at the proper measure. A solution that has been reached with the child's full cooperation will float his or her needs and difficulties to the surface and provide the child with an appropriate answer, and we will construct a personal work plan for the child and do this with the child's full cooperation. We will give the child a sense of security - a sense that he or she is in a protected space, one with belonging and empathy, with reciprocity, acceptance, and self-respect. We will not adopt "ready-made" programs constructed by someone else, nor programs we constructed with another child. We will gather information from various sources and construct a program that will enhance a meaningful process, because it is the process that is the developing and balancing factor. We will encourage children to talk about fears and about whatever makes them doubt that they might not succeed in the process. We will help children derive positive messages regarding the future out of their failures, fears, and success (Bornstein, 2003; Daloz, 1987; Fredrickson \& Joiner, 2002; Guissin, 2005; Huppert, Baylis, \& 
Keverne, 2005; Hussong, Zucker, Wong, Fitzgerald, \& Puttler, 2005; Kagan, 1982; Kashdan, 2007; Kashdan \& Steger, 2006; Lewis, Haviland-Jones, and Barrett, 2008; Winnicott, 1965; Zilka, 2014).

\section{The Elements Way: Constructing a Plan of Action}

As stated above, in the Elements Way, work is done in accordance with the individual needs of each child. Following are the stages of constructing a plan of action with the child's cooperation (Zilka, 2014):

Stage 1 - Questioning. As parents, educators, and mentors, we will ask ourselves What? How? Why? Wherefore? When? We will observe the mentor's awareness of the signals that the child sends. We will then identify the problem, describe it, and map it for clearing the fog and ascertaining strengths and weaknesses.

Stage 2 - The Dream. Formulating goals and objectives. Engage in constructive thinking about appropriate solutions. Learning from success and making decision based on these lessons.

Stage 3 - Planning the milestones and constructing a time table.

Stage 4 - Executing the plan of action.

The challenge facing adults who aspire to play a significant role in the life of children is to find ways to demonstrate empathy, acceptance, compassion, attention, and love, and assist the children in finding his or her own qualities. Adults have to consider the child as a complete human being who desires to grow and develop into a happy adult, connected to him or herself and the environment (Daloz, 1987; Judge \& Bono, 2000; Norcoss, 2002; Popper Mayseless, \& Castlnovo, 2000; Zilka, 2014, 2015).

\section{STUDY EXAMINING THE EFFECTIVENESS OF THE ELEMENTS WAY}

This study was designed to examine the effectiveness of mentors' work with immigrant children and adolescents at risk, using the Elements Way, to achieve goals and transformation. The children had been defined by Israeli welfare authorities as being children at risk. In addition to being the children of immigrants and defined as being at risk living in a risk environment, these children are exposed to online content and media that expand the range of risk. These sources and information channels cause great confusion, distraction, difficulties in focus and concentration, attention and adjustment problems, and a blurring of boundaries and values. The multitude of sources and information channels obligates us, more than ever, to be attentive to children, help them, and support them (Zilka, 2014, 2016b).

This mixed-method study was conducted from 2010 to 2013, and encompassed 640 adult mentors who worked with some 3200 immigrant children at risk. All mentors were adults. The children and adolescents ranged in age from 6 (first grade) to 17 (eleventh grade), and each mentor worked with five children of approximately the same age. They met with the children four days a week and an additional day was dedicated to studies and training of the Elements Way in a college of education. All mentors had been trained in the Elements Way prior to commencing their work with the children, with in-service training and support for the duration of their work with the children as part of their studies in college. Meetings took place during school hours with the mentors working with the children in their classrooms or individually outside the classroom during class hours, and again after school. All five children assigned to a mentor were enrolled in the same afterschool program after their regular school day.

The effectiveness - degree of success or failure - was examined according by the improvement in the child's wellbeing as reflected in the questionnaires, the interviews, and the protocols taken from the sessions held by the teachers, instructors, social workers, or other professionals who were in contact with the children. The following factors determined the mentor's degree of success or failure: 
- The work program that the mentor created and structured with the child and its practice and implementation; discourse analysis of all work programs;

- The mentors' self-reports regarding their work and a discourse analysis performed to the process as it was recorded and evaluated by the mentor himself;

- The patterns of communication between the mentor and the child from the mentor's point of view;

- Improvement of the child's performance academically, socially, and emotionally, according to reports provided by teachers, instructors, social workers, or other professional who were in contact with the children, along with observations conducted by the mentor while working with the children.

\section{IMMIGRANT CHILDREN AND ADOLESCENTS AT RISK}

Immigration is movement from one country to another. Many immigrants encounter hardship, beginning with language problems, and issues of housing, financial distress, and cultural and social adjustment difficulties. Often there is tension between the immigrants' cultural principles and their daily experiences with their new society, and these tensions and difficulties exacerbate the distress of immigrant children (Choi, 2008; Maldonado-Molina, Reingle, Wesley, Jennings, \& Prado 2011; Rossiter \& Rossiter, 2009; Spallek, Zeeb, \& Razum, 2010; Yearwood, Crawford, Kelly, \& Moreno, 2007). In Israel, immigrants are defined as "new immigrants" during their first three years in the country, and those arriving from Third World countries are considered "new immigrants" beyond that period.

The current definition of at-risk children is based on some 20 clauses from the 1989 United Nations Convention on the Rights of the Child, and on the 2006 Schmidt report. Both documents define atrisk children as individuals from birth to age 18 years who live in situations in which they are in danger from their family or environment. These conditions damage their ability to receive their rights for physical existence, health and development, belonging to a family, as well as their rights to learn, acquire skills, enjoy personal health and wellbeing, belong to society and participate in it, and being protected from others and from their own behaviors.

Among the possible conditions for rendering a child at risk are inadequate parental functioning, a parent's illness or death, neglect on the part of those responsible for the child, behavioral problems, problems of adjustment, financial difficulties, academic difficulties, social variance, immigration, belonging to a minority group, disability, transition from one setting to another, living in poverty, or living in a dangerous environment. These situations result in a child's defective functioning as well as in passivity, aggression, and even social deviance. Children who had been exposed to neglect and abuse are at greater risk to develop mental disorders and may have difficulties in developing a healthy, adjusted lifestyle (Etzion \& Romi, 2015; Kaim \& Romi, 2015; Romi, 2001; Romi, Savicki, Grupper, \& Caspi, 2007).

Some of the immigrants' children maintain online contact with friends and family in their country of origin, and some even daily. Others come from countries such as Ethiopia, were the internet is not sufficiently developed and, therefore, have no means of communicating with friends and family. The opportunity to communicate has a dual effect. On the one hand, it may ease the transition, as the internet "bridges" communication with those left behind. On the other hand, daily communication may create resistance to acclimating to the new country, to learn the new language, and to adopt the customs of their new home.

\section{METHOD}

\section{SAMPLE}

The study population consisted of 640 mentors who had applied to work with immigrant children at risk. The mentors worked with about 3200 immigrant children and adolescents at risk, who ranged in 
age from 6 (first grade) to 17 (eleventh grade). Most of the children who were assigned a mentor came from Africa and the Commonwealth of Independent States, and all were "new immigrants" living in Israel for three years and less. The children were all enrolled in schools, and mentoring took place during the school day and in after-school programs held until $7 \mathrm{pm}$. Each mentor worked with five children, of the same age range, and conducted the work either individually or with the group, depending on the needs at the moment.

The research was conducted from 2010 to 2013.

\section{METHODOLOGY AND RESEARCH TOOLS}

The research is a mixed-method study. For the most part, the methodology was qualitativedescriptive, and this was combined with quantitative methods according to the triangulation method of data validation. The research focused on discourse and included gathering data from observations, interviews, questionnaires, and conversations. The research employed winnowing techniques in order to present a thick description of the main findings. Ely, Vinz, Downing, and Mnzul (1997) and Wolcott (2001) claimed that winnowing is important for working with data as it enables the researcher to focus on the main findings and present the most significant and convincing research findings.

Success or failure in the mentor's method of work was examined according to an improvement in the child's wellbeing as reflected in the questionnaires, the interviews and the protocols taken from the sessions held by the teachers, instructors, social workers, or other professional who were in contact with the children. The following factors determined the mentor's degree of success or failure:

- A discourse analysis of the work program that the mentor created and structured with the child, and its practice and implementation;

- The mentor's self-reports regarding his work and a discourse analysis performed to the process as it was recorded and evaluated by the mentor himself;

- The patterns of communication between the mentor and the child from the mentor's point of view;

- Improvement of the child's performance academically, socially, and emotionally, according to reports provided by teachers, instructors, social workers, or other professional who were in contact with the children, along with observations conducted by the mentor while working with the children.

\section{QUESTIONNAIRES}

The questionnaires used for this research were filled in by the school staff, with special attention to questionnaires filled in by the homeroom teacher and the staff of the after-school child care facility. Questions referred to such issues as the children's academic, social, behavioral, emotional progress, and their conformance to norms, and their wellbeing. The questionnaires were almost identical, with adjustments for the differences between school and complementary settings.

The questions related to the children's situation and attitude, overall level of the class, and the expected achievements of his age group. Participants were asked to grade their evaluation on a 1-5 scale $(1$ - above average, 5 - fail) and add written explanations.

The school staff's questionnaire included items regarding each child (e.g., age, place of birth, family, etc.), followed by questions about the performance of the child in school (17 questions); age-appropriate academic performance (8 questions), self-efficacy ( 9 questions); school staff connection with the child's parents ( 1 question), the contribution of the after-school child care facility to the child (4 questions); and elaboration on the connection between the school and the complementary setting (2 questions).

The after-school staff's questionnaire included items regarding personal details; details about the afterschool child care facility; strengths and special skills of the child (1 question consisting of 13 items); 
the child's basic life habits (e.g., cleanliness, bringing required equipment, 7 questions); ageappropriate academic performance (8 questions); social performance in the after-school child care facility (11 questions); personal-emotional performance in the after-school child care facility (e.g., mood, body image, 7 questions); self-efficacy (9 questions) and a general question regarding the contribution of the after-school child care facility to the child.

Participants answered the questionnaires at different times throughout the period of mentor-child work:

1. Prior to the beginning of the intervention of the mentor, by the school staff and by the staff of the after-school child care facility;

2. Additional questionnaires were filled by the staff of the school and the after-school child care facility every three months.

\section{OBSERVATIONS}

Non-participant observations of children and mentors were performed as they worked. A total of 700 observations were performed, of which 300 were in school and 400 in complementary settings.

The observers focused on issues such as the manner by which conversations opened, the nature of interactions, expression during work sessions, and ways of coping with difficulties that arose. Observers also listened to the language used - compassionate vs. distancing, sharing emotions and sensation - and the mentors' ability to reflect on their work with the children.

\section{INTERVIEWS}

Various participants were interviewed during the research so as to provide different perspectives regarding the children, teachers, principals, and mentor in the field. Interviews were conducted with:

- 120 teachers whose students were assigned a mentor.

- 120 staff members in an after-school child care facility where a mentor was present.

- 160 children who worked with a mentor whose mentor had advanced them and 30 children who did not benefit from the mentor.

- 640 mentors - all the mentors were interviewed using an in-depth interview individually and in different periods of time throughout the entire period of their work.

\section{RESULTS}

The effectiveness of mentor's work with immigrant children and adolescents at risk, using the Elements Way to achieve objectives and transformation in immigrant children was examined in the present study. The children had all be defined by Israeli welfare authorities as being at risk. The examination revealed the following findings:

- 3350 children were registered for the program during the research period, and most completed it. One of the reasons that a child did not complete the program was the mentor's decision that he or she could not handle the child. The mentor was assigned other children.

- Programs for a total of 3200 children were created. Some of the children worked with mentors throughout one school year and some children worked with their mentors for two years, depending on the child's progress and in keeping with the laws providing special assistance to immigrants who have been in the country for over three years.

- Programs that had been created for 160 children were discontinued within the school year. The reasons for ending work included removal of children from their homes, sending children to alternative educational facilities, mistrust between child and mentor, the child's unwillingness to continue with the program, and the mentor's unwillingness to continue with 
the program. Some mentors asked to stop working with a specific child and remained in the program.

- 2800 children continued with the same mentor for more than one school year, with the mentoring usually lasting two years

Even though all mentors received identical training, significant differences were found in their behavior with the children.

- The vast majority, 578 mentors, were able to generate transformation in the children and achieve desired goals. They created programs which were implemented with consideration and consistency. Each time the goals had been reached, a follow-up program was constructed.

The mentors who were able to advance the children and were capable of establishing trust with them were those who worked according to the principles that were set in the training program. At the same time, these mentors examined themselves each time they felt a need to release pent-up feelings or when they felt insulted by the child. Mentors showed willingness to engage in dialogue with the child and devoted time for thinking, planning, and selfreflection before commencing a dialogue with the child.

Of the 640 mentors, 38 were not able to advance the child. Even when the mentor was assigned different children, the dynamics did not change. It was found that these 38 mentors lacked motivation to develop a significant empathic relationship with the children. They engaged in confrontation with the children, reproached them or insulted them.

The mentors who could not advance the children repeatedly used statements such as: "This child has problems that she brings from home. How can I be of any help?" "This child has no motivation to be in interaction. He is aggressive and I can't talk to him at all." "This child is ill-behaved and there's nothing that can be done to help him. It's too late and it's a lost cause. His behavior can't be changed." "Some children are lazy." "I find this attitude unacceptable. You shouldn't approach the child. The child should understand where he lives and conform to us. This program's approach isn't suitable for tough and aggressive children." "One must be strict with children and show them who's the boss." "He's rude. He's rude to his teachers. He's also rude to his parents and to me. He's not accepted social, and he's plain lazy and rude. He is impertinent with his parents and with me. He is socially unacceptable, lazy and impertinent." "I'm against the approach that places the child in the center. It leads to undesired results and it is a mistaken and disastrous approach." "There are children that you can do nothing about, you must raise your voice, be angry at them so that they understand that they are wrong."

- 24 mentors were able to create programs in coordination with the children, to engage in interactions with the children and accompany them. Yet an examination of the achievements revealed specific, restricted change, not changes of essence. When interviewed, these mentors raised different issues such as: "I was able to make the child understand his teachers' demands and behave like everyone else in the classroom but I'm not able to reach a significant dialogue with the child, a dialogue in which the child talks about his difficulties, his fears... I feel that what I did was to explain the 'administrative' or 'normative' demands to her, but I don't feel that I was genuinely able to reach the children." "Life is so tough on these children. How can they study when their situation is so hard? I don't think you can demand anything from them. It is enough that they get to school, enough that they reach the end of the day. How can one even function with these difficulties?" "Each child has so many problems, it is unbelievable. Health, study and family problems. No one can handle so many problems. What I mostly did was to let them feel that this is alright, that they are alright. No one can make them study." 
One noticeable example was that of Eleanor, a girl in the fourth grade. Whenever Eleanor came across difficult situations (for example, when meeting new people, or being in new places) she stopped talking. This silence created a barrier between Eleanor and others; she felt threatened by the others and refused to engage in interactions with other children. Eleanor's teacher said that Eleanor did not talk to her or other children in class. She listened in class yet her academic performance was unsatisfactory.

Eleanor was assigned to a mentor who began establishing a relationship of trust. In a quiet area in school, the mentor and Eleanor used to sit together and talk for many days. Eleanor told the mentor that she was afraid and that when she was afraid she became silent. She said it was better for her not to speak in class because "the teacher yells and all the children make fun, shout and laugh at each other."

When the mentor began accompanying Eleanor to class, Eleanor did not utter a word. Gradually she asked the mentor to speak on her behalf with the teacher or other children whenever she felt she had something to say. Slowly, and in small groups at first, Eleanor began talking. At first she whispered and then her voice became louder. She became more socially involved, in and out of class.

The mentor assisted Eleanor whenever Eleanor asked, without reverting to manipulations by using sentences like "you can do it on your own." She gradually made Eleanor aware of her difficulties, all the while considering Eleanor's ability to contain her words. As she became aware of her difficulties and her fears, Eleanor slowly began to overcome them, no longer avoided interactions. She wanted to be a part "of the real world."

\section{PASSIVE AND AGGRESSIVE CHILDREN.}

Sixty-two 62 mentors who did not succeed in their work or whose success was superficial level reported that they were getting along better with passive children (they referred to these children as "quiet" or "calm") and found it more difficult to handle aggressive ones. Yet findings show no improvement in the wellbeing of the passive children with whom these mentors worked, and the mentors were not able to develop significant and enhancing interactions with them. Passive children are often perceived as "good" children who do whatever they are told. Yet the goal is not to promote a behavior that would result in "blind obedience" and malleability, but to create individuals who not only react to a situation but whose actions are governed by an inner drive that may cause transformation.

During their studies in the academic college of education, 30 mentors were seemed to be "sealed" to what was happening around them. Another 24 underwent a slow, cautious process, as if afraid to engage in a significant interaction with the people around them. However, the Elements Way training transformed most of the mentors, who realized and understood that children need guidance and support and not supervision and labeling. They learned that the way to a child's heart, and to engage the child is through dialogue and through accepting the child as a whole - strengths, weakness, and all.

\section{EMOTIONS ARE PERMITTED YET THE ACTIONS ARE LIMITED}

Findings show that 598 mentors stated that one of the most prevalent and serious difficulties was handling the children's intense emotions, especially their anger and release of pent-up emotions. Mentors who respected and accepted the child's emotions provided children with a sense of power and strength to enable them to cope with their emotions. Mentors helped children identify their emotions, define them and explain them, and also helped them understand the role that emotions play in their life and in life in general. The connection between the mentor and the child was severed when the mentor did not respect or could not contain the children's emotions. 


\section{SELF-MONITORING}

Findings from the initial work of mentors with showed that most (629 out of 640) met with numerous difficulties stemming mostly from the gap that existed between their own self-perception and the child's perception of them. Mentors reported about being hurt by the children, feeling that the children did not appreciate their investment, and that the task at hand was "out of their league."

The 38 mentors who were not successful rejected the idea of self-reflection and insisted that the problem was with the child. To support this claim, they recruited other adults, such as teachers and other office holders who, like them, "did not succeed" with the child. They used sentences such as: "No one will be able to work with this child." "Even his parents are unable to handle him." "Her teachers gave up a long time ago." "He is an irritating and annoying child who likes attacking others. There's no way of working with him." These mentors were unable to put the child's wellbeing in the center as they remained focused on their anger at the child and the insult they suffered.

\section{CREATION OF A WORK PROGRAM FOR THE CHILD WITH THE CHILD}

The UN Convention on the Rights of the Child (1989) states that the central issue is the 'child's best interest'. The UN is dedicated to enhancing children and presenting them with equal opportunities to their peers. The 578 mentors who were successful in advancing the child, came up with a personal program for each child with the child's full cooperation. They internalized the difference between obedience-reaction and dialogue, acceptance, adjustment, and internalization. These mentors learned to be attentive to the child when the child met with difficulties, felt defeated, or failed.

The 38 mentors who did not succeed in their work with the child had not created a mutual program with the children and could not establish a reciprocal relationship with them, as in their interpretation, "cooperation" meant "informing." Rather than including the child in creating the program, they preferred to formulate goals and milestones which they then expected the children to reach. They did not devote time to create the program according to the Elements Way plan or the child's needs, and came up with laconic, general programs that and lacked quantifiable goals and objectives and were formulated as a set of instructions that had to be followed. For the most part, these mentors justified their course of action with statements such as: "This child should be told what to do and he should not be permitted to make a choice because then he is lost." "She has no idea what she wants and what she doesn't." "He doesn't deserve the time that I invest in him, he doesn't appreciate a thing." "I devote my time to her and she has no desire to help herself."

Mentors who succeeded in advancing children made sure that during the execution of the program (Stage 4 in constructing the plan of action) they did not intervene in a manner that would weaken the child yet they were still involved and caring and were able to create a well-structured system in advance that included mutual examination performed by the mentor and the child.

\section{DisCUSSION AND CONCLUSIONS}

In this study we examined the effectiveness of the mentor's work with immigrant children and adolescents at risk, in the Age of New Media; using the Elements Way as a methodology for achieving objectives and transformation in the work of mentors. The study was conducted in 2010-2013, and encompassed 640 mentors working with about 3200 immigrant children at risk.

Significant differences were found in the ways mentors behaved with the children. Those who were able to lead the children toward significant achievements and changes had begun by creating work programs in cooperation with the children, and the program was implemented in a sensitive and consistent manner with the mentor setting a personal example. Each time a goal was met, a new followup program was mutually created by the mentor and child.

Mentors who were able to advance the children and engage in a relationship that was based on trust were those who followed the principles of the Elements Way. Throughout their work, the mentors 
kept on clarifying issues as they came up, especially when the mentors had to release pent-up emotions or felt insulted by the child. Mentors learned how to listen to the children and engage in an existential dialogue with them in such a manner that enabled the children to feel that they belonged to their society and surroundings, and were wanted by them.

The main difference between an existential dialogue and theoretical discourse is that an existential dialogue strengthens the existing relationship and conveys the message "You are not alone. I am with you." The goal is not to settle for discussions of the problems but to relate to the children and to the difficulties they experience as existential problems that can be solved, not only thought about or mulled over. The mentor leads the child through a process of awareness, reflection and thought in relation to the problem and the ways of dealing and solving it.

\section{SUCCESSFUL MENTORS}

Mentors who were able to advance the children described their function as aimed at assisting the children and reaching out to them in times of need. The also saw their function as working making the children feel secure in their relation to the people around them, as well as instilling in the children a sense of trust and belonging. These mentors perceived themselves as role models, and as such were careful neither to interrupt nor blame so as to be worthy of their role. They tried to convey peace of mind and tranquility instead of stress. They treated the children with respect and refrained from using generalizations and accusations, and when children behaved badly they treated each incident separately, and together with the child devised a program aimed at helping that child change his or her behavior.

The successful mentors sought to present the child with transparency, a sense of order, discipline and cause and effect. They worked toward creating an orderly environment, without chaos or vague rules. The successful mentors helped children understand the relationship between their behavior and the behavior of those around them, as well as the effect of their e actions on themselves and their surroundings. Their involvement was containing and supportive and served as guidance in the life of the child while establishing clear-cut boundaries. These mentors gave the children a feeling that they "were there" for them, and accepted them as a whole person who wanted to develop and opt for the good.

Successful mentors found the time and the patience to listen to the children without making them feel humiliated, inferior, or stupid. They shared the children's areas of interest, all the while holding the child as their top priority. In every interview conducted with successful mentors, they expressed their satisfaction and their willingness to continue with their work. During their studies in the academic college of education they showed active participation in the different academic courses.

\section{UNSUCCESSFUL MENTORS}

Of the 38 mentors who were not successful in their work, some did not follow the principles of the Elements Way, and even expressed disapproval of these principles. Despite the fact that the principles are closely linked to the child's wellbeing, interviews with these mentors revealed that their method of work with the children originated out of different insights they accumulated throughout the years and became a part of their "critical self"; such insights included punishments, strictness, humiliation, confrontation, and denigration of the children.

Most of the 38 mentors who failed found it difficult to accept the role of the assisting, supportive yet noncritical mentor. Instead, they viewed their role overseeing whether the children did their homework, sat quietly in class, and followed instructions; they did not perceive themselves as having to establish a trusting relation with the children. These mentors kept their distance from the children. They preferred giving orders to developing significant interactions with the children, and through these interactions perhaps achieve intimacy and of understanding the child's difficulties and causes of his or her delayed development. 
These findings confirm previous approaches and findings (Bornstein, 2003; Daloz, 1987; Guissin, 2005; Huppert et al., 2005; Hussong et al., 2002; Kagan, 1982; Kashdan, 2007; Kashdan \& Steger, 2006; Lewis et al., 2008; Winnicott 1965; Zilka 2014). These researchers found that a mentor's inability to place children and their needs at the center creates communication problems with children. It also indicates that the child cannot be accepted as he or she is, and prevents advancing the child toward mental wellbeing.

\section{Passive children}

These children will suppress their will and render their wishes invisible to themselves; they will perform the tasks that are required from them in order to "survive." The message that these children receive is that they are unwanted, unimportant, and not taken into account. These children are not autonomous nor responsible for their lives and their decisions - there is someone else who is in charge of their lives.

\section{Aggressive children}

Aggressive children, will rebel and fight for their sense of selfhood, and their resistance will result in conflict, a situation in which usually everyone loses. Often, the situation tends to escalate. During times of conflict the mentor used words that the child could neither "bear" or contain, causing significant damage to the child's self-perception. The child is rendered feeling isolated, lacking support, love, or compassion.

Both types of children - aggressive and passive - refrained from developing significant interactions that might have led to an educational process. There was no transformation with mentors who did not establish positive connections with them and no significant change was observed in their achievements and wellbeing.

When the mentors identified that the passive or aggressive behavior hindered the quality of their interactions with the child and wanted to initiate a change in the child's behavior, they had to assist the child by emphasizing or downplaying certain aspects of that behavior. To be aware of these aspects, mentors have to observe the child, formulate the nature of the problem with the child, engage in a dialogue that will lead the child toward awareness of his or her behavior and, consequently, bring out the child's own will to change that behavior.

Mentors who were not successful in advancing the child, saw themselves as figures "who had to finally put the child in his right place." They gave orders to the child, imposed conditions and punishments, and expected the child to obey. They created a tense, judgmental atmosphere, fraught with criticism. They refused "to take responsibility" over the children, belittled their feelings, will, and dignity. They evinced a lack of patience when listening to the children and described them as manipulative, lying and violent.

Unsuccessful mentors did not generate a feeling of protection and belonging in the children. They preferred to use a distancing language instead of a language that drew the children closer; some even used provocative language. They often interrupted the children's words. Indeed, they created a work program for the child yet the atmosphere was grim and the work program was written in a laconic, general, and vague style quite the opposite of programs that were written together with the child and introduced a meaningful process to the child and the mentor alike (the mere mutual activity of creating the program together, making the atmosphere clear and so on). Mentors who did not succeed in their work did not encourage the child to talk about his or her concerns, fears, and the possible obstacles on the way to the success of the process. They found themselves arguing with the children, conducting monologues instead of dialogues. 


\section{Self-cleansing (self-monitoring)}

One of the basic tools that mentors acquired during their training was self-cleansing (Zilka, 2014). This was an essential tool for situations in which a child said something that made the mentor angry or lose control. In such cases, the mentor had to ask him/herself the following questions: Why did the child's behavior/words raise such a strong emotional reaction in me? Why did I react the way I did and why did these words make me feel sad (and/or defensive, hurt, humiliated, being judged, under attack?) The mentors were taught to let the child's words or behavior be a trigger for selfreflection and self-cleansing. The underlying idea is that the anger and insult that had emerged and were released had already been within the mentor, because, if this were not the case, the mentor would have related to the specific behavior. Thus, if the child behaved in a disrespectful manner, the mentor would have reacted to that behavior and shown the child ways to reshape his or her behavior, but the mentor would not have been insulted. It was up to the mentor to connect with this emotion so as to mitigate and purge it.

Self-reflection was rejected by some of the 38 mentors who were not successful in their work, and who insisted that the problem was with the child. As stated above, they recruited other education professional who know the child to support their claim. They were unable to put the child's wellbeing in the center as they remained focused on their anger at the child and the insult they suffered from the child.

\section{SUCCESS}

The findings yielded several factors common to mentors whose work with children was successful:

- Self-awareness and awareness of one's surroundings.

- Empathy.

- Willingness to engage in significant interactions.

- Self-cleansing and self-reflection.

- Ability to engage in a personal and interpersonal dialogue.

- Ability to accept and contain the child.

- Cooperation with the child in creating a work program and assisting the child to achieve the goals that were set in the program.

\section{FAILURE}

Research findings show that failure usually stemmed from the tendency of the mentor to accept defective and reductive solutions for complex and irritating problems. Some reasons pertaining to the failure of the process and the failure to attain the desired achievements include:

- The mentor created the work program independently, without the child's cooperation.

- No measurable operative goals were defined.

- No specific achievements were defined.

- The work program did not enable a significant and enjoyable process.

- No clear and operative stages that could be implemented by the child were defined.

- The mentor had no motivation to encourage the child to make an effort in the process.

- The mentor showed lack of resilience and endurance.

- The mentor did not dedicate sufficient attention to detail.

- The mentor was rigid, dishonest, and lacked integrity.

- The mentor did not undergo a process of reflection. 


\section{IN WHAT WAYS CAN WE HELP A CHILD UNDERGO TRANSFORMATION?}

- Reach a variety of alternatives together with the child.

- Never judge a child.

- Never elicit the child's guilt.

- Teach the child simpler techniques for improvement such as reflection, analysis of actions in real time and in retrospect; seeing and dealing with reality instead of beating around the bush; understanding the connection between thoughts-emotions-behaviors.

- A reflective process may result in a change in the child's manner of thought.

- The child's outlook on reality should be realistic, with vision that is not clouded by worries, as such an outlook creates a gap between reality as it is and its perception.

- Assisting the child to understand "cause and effect" connections.

- Not taking everything too seriously. The tactic of "reenacting" reality helps to open the child's mind.

- Helping the child to accept himself for what he is means that the adult shows the child that he accepts him for what he is. The child will learn to accept himself and the other as he is and from the point of self-acceptance to generate a desired change stemming from his own choice.

\section{LIMITATIONS AND RECOMMENDATIONS}

Part of the important insights in this study was derived from an analysis of the mentors' conversations with the children and adolescents. Despite the objective difficulties that children have in defining and generalizing, talks with them could yield generalizations and insights as to who they would prefer as mentors.

However, because of the wide scope of the study, the vast data collected, and because of our desire to ground these data and reach solid insights, we concentrated on the mentor's training and focused on discourse analysis related to the mentors' work and difficulties, and less so to the various needs that the children raised in their talks with the mentors and other staff members during the interviews and observations.

Future studies should focus on analyzing the discussions of children and adolescents, to add depth to our insights regarding children and adolescents' perception of the mentors' work from their perspective.

\section{REFERENCES}

Atwal, K., Millwood Hargrave, A., Sancho, J., Agyeman, L., \& Karet, N. (2003). What cbildren watch: An analysis of children's programming provisions between 1997-2001. London: BSC/ITC.

Bickham, D. S., \& Rich M. (2006). Is television viewing associated with social isolation? Roles of exposure time, viewing context, and violent content. Archive of Pediatric and Adolescent Medicine, 160(4), 387-392.

Bornstein, M. H. (2003). Well-being: Positive development across the life course. Mahwah, NJ: Lawrence Erlbaum.

Choi, Y. (2008). Diversity within: Subgroup differences of youth problem behaviors among Asian Pacific Islander American Adolescents. Journal of Community Psychology, 36(3), 352-370.

Comstock, G. A., \& Scharrer, E. (2007). Media and the American child. Amsterdam; Boston: Academic Press.

Daloz, A. L. (1987). Effective teaching and mentoring. San Francisco \& London: Jossey Bass.

Duerager, A., \& Livingstone, S. (2012). How can parents support children's internet safety? London, UK: London School of Economics, EU Kids Online.

Ely, M., Vinz, R., Downing, M., \& Mnzul, M. (1997). On writing qualitative researcb: Living by words. New York \& London: Routledge. 
Etzion, D., \& Romi, S. (2015). Typology of youth at risk. Children and Youth Services Review, 59, 184-195.

Fredrickson, B. L., \& Joiner, T. (2002). Positive emotions trigger upward spirals toward emotional well-being. Psychological Science, 13, 172-175.

Gatfield, L., \& Millwood Hargrave, A. (2003). Dramatic license - Fact or fiction? London: Broadcasting Standards Commission.

Guissin, S. (2005). Developing reading and creative writing skills among children at risk. Brighton, UK: Sussex University press.

Hamre, B. K., \& Pianta, R. C. (2001). Early teacher-child relationships and the trajectories of children's school outcomes through eighth grades. Child Development, 72, 625-638.

Hamre, B. K., \& Pianta, R. C. (2005). Can instructional and emotional support in the first-grade classroom make a difference for children at risk of school failure? Child Development, 76, 949-967.

Hamre, B. K., Pianta, R. C., Downer, J. T., \& Mashburn, A. J. (2008). Teachers' perceptions of conflict with young students: Looking beyond problem behaviors. Social Development, 17(1), 115-136.

Holbert, R. L., \& Stephenson, M. T.(2003). The importance of indirect effects in media effects research: Testing for mediation in structural equation modeling. Journal of Broadcasting and Electronic Media, 47, 556-572.

Howes, C., \& Ritchie, S. (2002). A matter of trust: Connecting teachers and learners in the early childhood classrooms. New York: Teachers College Press.

Huppert, A. F., Baylis, N., \& Keverne, B. (2005). The science of well-being. Oxford: Oxford University Press.

Hussong, A. M., Zucker, R. A., Wong, M. M., Fitzgerald, H. E., \& Puttler, L. I. (2005). Social competence in children of alcoholic parents over time. Developmental Psychology, 41, 747-759.

Judge, T. A., \& Bono, J. E. (2000). Five factor model of personality and transformational leadership. Journal of Applied Psychology, 85, 751-765.

Kagan, R. (1982). The evolving self: Problems and process in human development. Cambridge, MA: Harvard University Press.

Kaim, Z., \& Romi, S. (2015). Adolescents at risk and their willingness to seek help from youth care workers. Children and Youth Services Review, 53, 17-23.

Kashdan, T. B. (2007). Social anxiety spectrum and diminished positive experiences: Theoretical synthesis and meta-analysis. Clinical Psychology Review, 27, 348-365.

Kashdan, T. B., \& Steger, M. (2006). Expanding the topography of social anxiety: An experience sampling assessment of positive emotions and events, and emotion suppression. Psychological Science, 17, 120-128.

Leung, L. (2013). Generational differences in content generation in social media: The roles of the gratifications sought and of narcissism. Computers in Human Behavior, 29(3), 997-1006.

Lewis, M., Haviland-Jones, J. M., \& Barrett, L. F. (2008). Handbook of emotions. New York: Guilford Press.

Livingstone, S. (2007). Evaluating the online risks for children in Europe. Telos, 73, 52-69.

Livingstone, S. (2008). Taking risky opportunities in youthful content creation: Teenagers' use of social networking sites for intimacy, privacy and self-expression. New Media \& Society, 10(3), 459-477.

Livingstone, S. (2015). From mass to social media? Advancing accounts of social change. Social Media and Society. Available at http://journals.sagepub.com/doi/abs/10.1177/2056305115578875

Livingstone, S., Marsh, J., Plowman, L., Ottovordemgentschenfelde, S., \& Fletcher-Watson, B. (2015). Young children (0-8) and digital technology: A qualitative exploratory study - National report - UK. Luxembourg: Joint Research Centre, European Commission.

Maldonado-Molina, M., Reingle, J. M., Wesley, G., Jennings, W. G., \& Prado, G. (2011). Drinking and driving among immigrant and US-born Hispanic young adults: Results from a longitudinal and nationally representative study. Addictive Behaviors, 36(4), 381-388.

McQuail, D. (2010). Mass communication theory: An introduction. London: Sage. 
Millwood Hargrave, A. (2007). Issues facing broadcast regulation. London: Broadcasting Standards Authority. Available at http://www.bsa.govt.nz/publications/IssuesBroadcastContent-2.pdf

Millwood Hargrave, A., \& Livingstone, S. (2009). Harm and offence in media content: A review of the evidence (2nd revised ed.). Bristol, UK: Intellect.

Myers, S. S., \& Pianta, R. C. (2008). Developmental commentary: Individual and contextual influences on student-teacher relationships and children's early problem behaviors. Journal of Clinical Cbild and Adolescent Psychology, 37, 600-608.

Norcoss, J. C. (2002 Ed.). Psychotherapy relationships that work. New York: Oxford University Press.

Ofcom. (2006). Media literacy audit: Report on media literacy amongst cbildren. London: Ofcom. Available at http://www.ofcom.org.uk/advice/media literacy/medlitpub/medlitpubrss/children/children.pdf

Ofcom. (2007). New news, future news. London: Ofcom. Available at http://www.ofcom.org.uk/research/tv/reports/newnews/newnews.pdf

Pianta, R. C., Belsky, J., Vandergrift, N., Houts, R., \& Morrison, F. J. (2008). Classroom effects on children's achievement trajectories in elementary school. American Educational Research Journal, 45, 365-397.

Pianta, R. C., Hamre, B., \& Stuhlman, M. (2002). Relationships between teachers and children. In W. M. Reynolds \& G. E. Miller (Eds.), Comprehensive handbook of psychology (Vol. 7): Educational psychology (pp. 199-234). New York: Wiley.

Popper, M., Mayseless, O., \& Castlnovo, O. (2000). Transformational leadership and attachment. The Leadership Quarterly, 11, 267-289.

Rideout, V. J., Foehr, U. G., \& Roberts, D. F. (2010). Generation M2: Media in the lives of 8-18 year-olds. Kaiser Family Foundation. Available at https://kaiserfamilyfoundation.files.wordpress.com/2013/01/8010.pdf

Rimm-Kaufman, S. E., La Paro, K. M., Downer, J. T., \& Pianta, R. C. (2005). The contribution of classroom setting and quality of instruction to children's behavior in kindergarten classrooms. Elementary School Journal, 105, 377-394.

Romi, S. (2001). Child and youth care in Israel: Trends and dilemmas in training and in therapeutic intervention programs. Journal of Child and Youth Care Work, 15-16, 171-184.

Romi, S., Savicki, V., Grupper, E., \& Caspi, R. (2007). Occupational burnout among child welfare workers: A work-setting comparison. International Journal of Cbild and Family Welfare, 10, 93-109.

Rossiter, M. J., \& Rossiter, K. R. (2009). Immigrant youth and crime: Stakeholder perspectives on risk and protective factors. Working Paper No. WP02-09.

Seligman, M. E. P., Steen, T. A., Park, N., \& Peterson, C. (2005). Positive psychology progress: Empirical validation of interventions. American Psychologist, 60, 410-421.

Schmidt, H. (2006). Report of the Public Committee on the Situation of Children and Adolescents at Riske and in Distress. (Hebrew). Submitted to the Prime Minister and the Minister of Welfare. Retrieved from http://www.sheatufim.org.il/multimedia/upl doc/doc 130708 4727.pdf

Spallek, J., Zeeb, H., \& Razum, O. (2010). Prevention among immigrants: The example of Germany. BMC Public Health, 10, 92.

Vandewater, E. A, Bickham D. S., \& Lee J. H. (2006). Time well spent? Relating television use to children's freetime activities. Pediatrics, 117(2), e181-e191.

West, R., \& Turner, L. (2007). Introducing communication theory. New York: McGraw Hill.

Winnicott, D. W. (1965). The maturational process and the facilitating environment. New York: International University Press.

Wolcott, H. F. (2001). Writing up qualitative research. Thousand Oaks, CA: Sage.

Yearwood, E. L., Crawford, S., Kelly, M., \& Moreno, N. (2007). Immigrant youth at-risk for disorders of mood: Recognizing complex dynamics. Arcbives of Psycbiatric Nursing, 21(3), 162-171. 
Zilka, C. G. (2014). Empowering educators \& mentors in the social media age - The Three Element Way (Hebrew). Tel Aviv: Bitan-Galim.

Zilka, C. G. (2015). Social competence of children at risk: Similarities and differences among the various assessors. In E. Grupper, \& S. Romi, S. (Eds.), Children and adolescents at risk in Israel (Vol 2). The voice of young people and issues faced by child and youth care workers (Hebrew) (pp. 85-113). Tel Aviv: MOFET

Zilka, G. C. (2016a). Reducing the digital divide among children who received desktop or hybrid computers for the home. Journal of Information Technology Education: Research, 15, 233-251. Retrieved from http://www.informingscience.org/Publications/3519

Zilka, G. (2016b). Do online friendships contribute to the social development of children and teenagers? The bright side of the picture. International Journal of Humanities and Social Science (IJHSS), 6(7). Retrieved from http://www.ijhssnet.com

\section{BIOGRAPHY}

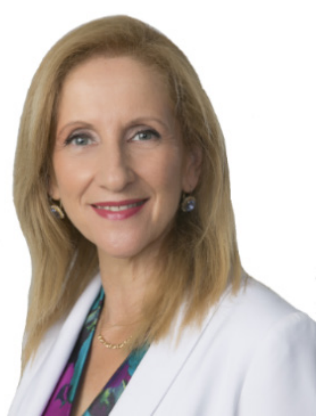

Gila Cohen Zilka, Ph.D., Director of the Department for Teaching Social Studies and Communication at Bar-Ilan University; Head of the program for training mentors to work with children at risk, Achva Academic College, Israel. Zilka's research focuses mainly on ICT, children in the digital environment, and communication in the diversified media. Zilka published two books that offer ways to empower children, parents, and educators in our age. For parents, "Empowering Parents in the Social Media Age - The Three-Element Way," and for educators and mentors, "Empowering Educators and Mentors in the Social Media Age - The Three-Element Way." 